$\left(\left(\left(\left(\left(\begin{array}{ll}\text { 解 } \text { 説 })))))) \\ \end{array}\right.\right.\right.\right.\right.$

\title{
走査トンネル顕微鏡
}

$\begin{array}{lll}\text { 桜 } & \text { \# 利 } & \\ \text { 酒 } \text { 井 明 }\end{array}$

1 はじめに

物質の原子構造を研究している者にとって，物質の原 子の配列を直接に，あたかも点眼鏡を柕くように、観察 するということは，昔からの変わら如夢である。この願 望は, 表面研究者の場合. より一層切実なもの亡なる。 よいうのも，物質の表面の原子配列は，物質の内部の原 子配列とは必ずしも一致してお放ず，しかも固体物理で 広く用いら机る電子線回折等の手法では, 表面の原子構 造を一意的に決定することが困難なのである，超高分解 能電子顕微鏡などの分析技術の進歩の時代にあっても， 物質表面の原子構造の直接観察の価值书よび難かしさは いささかも減じては㧍らず，ここで述べるSTM (走相 トンネル顕微鏡）が 1986 年の Nobel 物理学賞の対象上 なったこ上も，そのような状況を明りょうに示している と言えよう。ところが，今から 35 年以上も前に，既に 金属の表面の原子配列直接肉眼で観察できる装冝が発 明されているのである。

その装置は, 1951 年に E.W. Muoller 教授によって 発明された FIM(電界イオン顕微鏡)である゙．FIM は図 1 に示されるように，基本的には試料とスタリーン から成る簡単な装置であり，試料としては，先端を鋭く 尖らせた（曲率半径 $1000 \AA$ 以下）金属の針が用いられ る.この針に $10 \mathrm{kV}$ 程度の正電圧在加えると、針の先 端の表面原子近傍の電界は非常に強くなり(数 $\mathrm{V} / \AA$ に 達する），装置内に少量の希ガス $(\mathrm{He}, \mathrm{Ne})$ を奨入する と, 希ガス原子は針の表面原子の直上でイオン化され る，生じたイオンは針の電界に反発され，10 cm ほど離 机たスクリーン上に, 表面原子と 1 対 1 に対疬した輝点 を作り出卞。その結果として、針の表面原子配列が、イ オンによってスクリーン上に拡大投影されることにな る. FIM の拉大率沽 $10^{5}$ 倍に達し，金属の表面原子配 列の美しい投影図をスクリーン上で容易に観察するこよ ができる(図1(b)).

東京大学物性研究所（齿106 東京土港区六本木 7-22-1)

，怢式会所東芝総合研究所（画210川崎市幸区小向東芝町1）
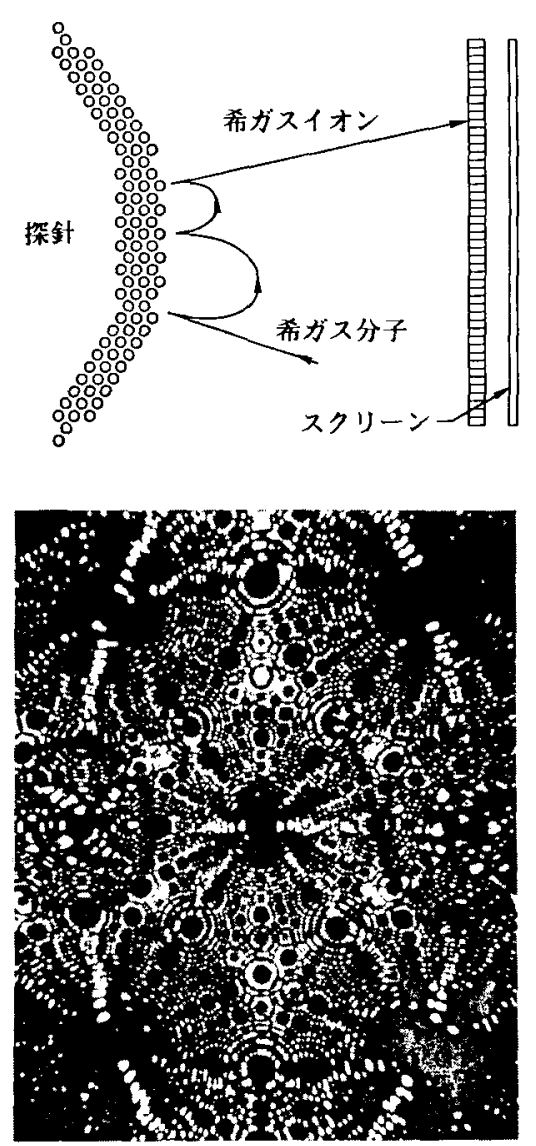

図 1 FIM の原理 ((a)) 交上び,W探針のFIM 像 ((b))

その素晴らしい高分解能にもかかわらず，FIMはあ まり表面の構造解析に用いられることはなく，こ机まで は，むしろ金属学の分野で積極的に使用されてきた。 れには，いくつかの理由があるが，その1つは，FIM では平たんな広い表面の原子イメージが得られないこと 
である. 図1(b)においても，低指数面の外縁の原子は 見えているが，面内の原子配列は観察することができな い. FIM では，原子面の端にある原子や，原子面上の 孤立した原子・原子集団がもっぱらイメージされるので ある。

FIM の手法は金属学ばかりではなく、いくつかの技術 分野に対しても重要な寄与を与えている．たと元ば電子 顕微鏡の電界放射源や，液体金属イオン源に用いられる 針状のエミッターの評価には，FIM は欠かせない手法 である.FIM の応用の際の重要な特徵は，エミッター の表面形状を原子レベルで制御できるこよである．FIM の針状試料に加える電圧を十分に大きくすると，表面 の原子そのものがイオン化して表面から脱離する現象

(電界蒸発) が起きる. 電界蒸発の様子は FIM で直接 モニターすることが可能であり，また高電圧パルスを印 加することによって，電界蒸発の速さを制御することも できる．この手法を上手に利用すると，じょじょに少し づつ表面原子を蒸発させ針の先端に数個の原子を残して おくことも困難ではない。

さて，FIMの場合には針に高電圧を加えて表面での 電界を高めているが，もしも針と対向電極を $100 \AA$ 以 下にまで接近させれば，低い電圧でも高電界を得ること ができるはずである．針を負電位にする上針からの電子 の電界放射が起きるが，この放射電流は電界の強さに敏 感であり，したがって針と電極間の距離によって大きく 変化する．このことに注目して針による試料表面の起伏 の測定を考案したのは，NBSのYoungである，彼は FIMの発明者 Muoller 教授の下で FIM の実験在行 なった経験があり，針からの電界放射を利用するこ上 は，彼にとって自然な発想であったと思和机る. 1971 年に Youngは協力者上よもに針の位置を電圧素子 $(\mathrm{PZT})$ で制御する機構を開発し，タングステンの針を 白金電極に数丸まで近づけることに成功している。この 距離では，電子は電界の助けがなくとも，トンネリング によって直接針と試料間を往来することが可能であり， 実際Young らは，針と試料間の距離を小さくすると電 界放射電流がトンネル電流に遷移することを見いだして いる22．このトンネル電流も針亡試料間の距離に敏感で あるので, トンネル電流の変化から試料 (電極) 表面の 凹凸を探ることが可能である。この目的に浴って Young らによって作られた装置は Topografiner と呼 ばれ，これは今日の STM の特徵を総て備えている装置 である(針の使用，トンネル電流の検出とそ扟を一定に 保つサーボ機構. PZT に上る針位置の制御之走查. 等々，図 2 参照）。Topografiner は面内方向の分解能 数干 $\AA$ を示し，回折格子の像を観察するこ上が出来た が，惜しむらくは原子を見るには至らなかった。民の後 この装置の開発プロジェクトは中止され，Young もこ

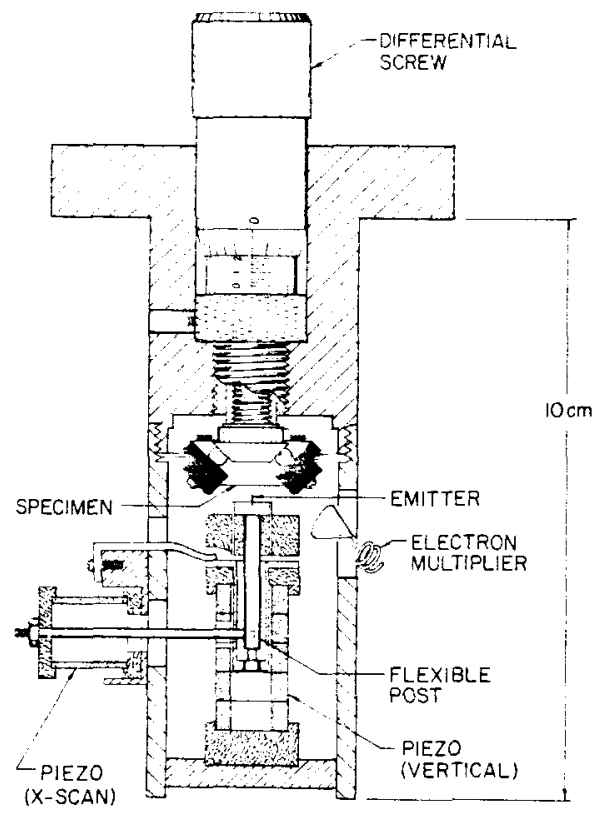

図 2 Topografiner の模式図

の種の装置で原子を観察することに悲観的な立場上な り，STMの萌芽上も言える研究は，発展することなく 終わってしまったのである。

IBM Zurichでは Binnig と Rohrer が Young 上は まったく独立に真空トンネリングの実験を1978 年頃か らスタートさせ，装置の除震に多くのくふうを試みた結 果，1981 年には探針上試料間を流れるトンネル電流を 精度良く制御することに成功している，更に装置の改良 を進め, 彼らの最初の表面観察の結果は1982 年に報告

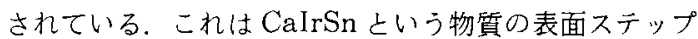
の観察例であり，まだ原子像は得られていなかったも の，STM という新手法はいくらかの注目を集めること となった. Binnig 上 Rohrer は次いで STM ユニット を超高真空装置に入机，当時表面科学で最も論議を集め ていた Si (111) 表面の $7 \times 7$ 構造の解明を試みたので ある。この大胆な挑戦は大成功を納め，彼らが得た $\mathrm{Si}$ (111) $7 \times 7$ STM 像は世界の表面科学者に少なから

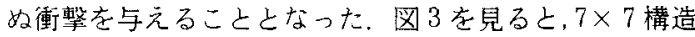
の菱形の単位胞の 4 隅にある深い凹みと，巣位格子内の 12 個の原子が明りょうにイメージされていることがわ 加。

図3からBinnig らが導き出した構造モデル自身はそ の後の研究で不十分なものであるこ之が明らかになった が, 彼らのSTM 像はSi (111) $7 \times 7$ の従来の多く構造 モデルの大半を一瞬にして葬り去り，“百聞は一見にし かず”上いう直接観察の威力を示したので南った，Si (111) での STM の成功は各国での STM 開発を加速す 


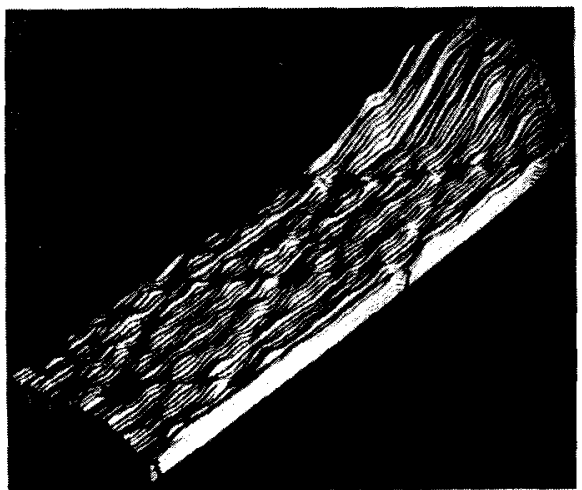

図 3 Binnig らによって得られた Si (111) $7 \times 7$ の STM 像, 2つの菱形のユニット・セルとその四隅の凹 み，およびセル内の 12 個の凸部 (adatom) が見られ る

ることとなったが, 1985 年までは、STM の実験結果は IBM Zurich の独占であった.しかし1985 年頃から Bell Labs $の$ Golovchenko, IBM Yorktown Heights の Feenstra および Demuth の各グループが半導体表 面の高分解能 STM 像を数多く報告するようになり，表 面構造解析法としてのSTM の地位が確立されるに至つ ている ${ }^{6)}$.

\section{STM の理論}

STM の基本原理は既に良く知られているが，ここで 簡単に紹介しておくことにする．STMは，单純には金 属の探針で試料表面を走查する装置であり，その点では 接触式の表面粗さ計に似ている. しかしSTMでは探針 は表面から $10 \AA$ 程度離机ており，針は表面には接触し てはいない，非接触ではあっても，針と表面との距離が 小さいために両者の間にはトンネル電流が流れ、この電 流の大きさが針と表面の距離に㐫じて変化するため，卜 ンネル電流が一定になる上うに探針位置を制御しながら 表面を走査すると，探針は表面の起伏に㳂って上下動す る.この探針の動きを電気的に検出して表面の起伏を探 る装置が STM である（図4）・トンネル電流は探針試料 間の距離に対して指数関数的に变化するため, STM は 表面の起伏に対して著しく敏感であり，表面に垂直な万 向の分解能は $0.01 \AA$ にまで達しえる. 他の手段では達 成できないこの垂直方向の高分解能が、STM で原子が 観察できるおもな理由であり，またSTMの重要な特徴 の1つともなっている.

㛜密に述べると，STMの基本原理についての上記の 説明は正確ではない，というのも，10丹程度のスケール の世界では，探針と表面の“距離”を適切に定義するこ 亡が困難だからである。試料の表面電子も，探針の表面 電子も，表面から外に〜 $10 \AA$ 程度浸み出しており，“表

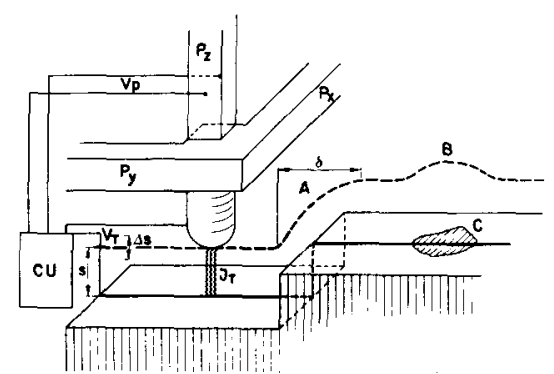

図 4 STM の模式図, Px, Py, Pzは探針移動用のピエ ゾ素子, $\mathrm{Cu}$ は制御ユニットで，トンネル電流 J、がー 定となるように, $\mathrm{Pz}$ に電压 $\mathrm{Vp}$ を加える. V、はバイア 不電圧，A，B はステップおよび不純物 $\mathrm{C} に$ 於ける探針 の軌跡を示す

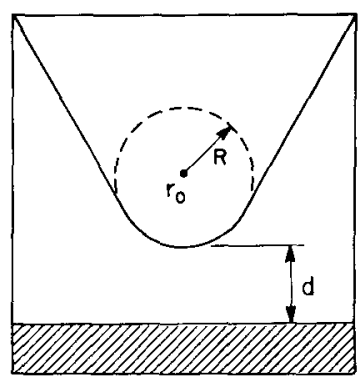

図 5 Tersoff 一Hamann 理論において仮定された探針 先端の形状

面”そのものが，その程度“ぼやけて”いるのである． トンネル電流は探針の表面電子の浸み出し部分之試料の 表面電子の浸み出し部分との重なりに比例しているの で, STM の理論的な取り扱いのためには，表面からの 電子の浸み出し, すなわち表面の外での電子の波動関数 の振舞いを取り入れた量子力学的計算が必要になってく る.

STM の量子力学的な取り扱いはいくつか行なわれてい るが, 現在最も標準的な理論となっているのが Tersoff とHamannによる理論である。波ら注探針先端を曲 率半径 Rの球状であると仮定し, 探針の電子の波動関数 として球対称の $\mathrm{s}$ 波を採用してトンネルコンダクタンス の計算を行なった（図5).結果は, “STM のトンネルコ ンダクタンスは，探針の曲率中心の位置（図 5 では表面 から $\mathrm{R}+\mathrm{d} の$ 位置) における試料の表面電子の Fermi 準 位での状態密度 $\rho に$ 比例する”，というものである。こ の理論によると，探針は表面の起伏に沿って動くのでは なく，むしろ○が一定であるような曲面，言わば “等局 所状態密度面”とでも言うべき面に沿って動くことがわ かる.

STM の探針がのの分布に従って動くことは，後述する 上うに半導体表面の STM 観察の際に確かめられてお 
り，既に確立されたことであると言っても差し支えない であろう。しかし，トンネルコンダクタンスが試料の状 態密度に比例することは，STM に限らずトンネル現象 全般に言えることであり，したがって STM が登場した 時点で, STM が $\rho$ を探る手法であることは表面物理学 者によって自明のことであったはずである，そ机伸え， Tersoff とHamann の理論は，この自明のことを具体 的に定式化したこと，STM の分解能の簡単な理論式を

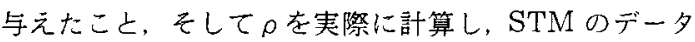
との比較から図 5 のR+dの値を推定したこと，等にそ の真価があると思われる，特に実際に $\rho$ を計算している 点は彼らの理論の強みであり，Hamannによって開発 されたSLAPW 法が勃力を発揮している。

Tersoff 上Hamann の理論は探針上試料間の電位差が 0 の極限の場合であるが，半導体の STM 観察では通常 数Vのバイアス電圧を探針試料間に加える．有限バイア スの場合にも，STM 像が試料表面の局所状態密度の分 布を表わしているこ上が理論的に導かれるが，そのとき の局所状態密度は $\rho\left(\varepsilon_{f}\right)$ ではなく $\rho\left(\varepsilon_{f}-\mathrm{eV}\right)(\mathrm{V}$ はバイアス電圧)である。したがって STMで試料表面 を走査しながらバイアス電压をスイープすると，表面の 電子状態密度のエネルギー依存性を表面の各点で測定す ることができる。固体物理学で知られているように，固 体の電子的な性質は状態密度で決まってしまうため。こ れまで多くの実験手法によって状態密度が調べられてき ている。しかし従来得られた状態密度は，マク口な領域 にわたって平均化されたものであり，最も基本的な個々 の原子点での局所状態密度は、これまで得ることができ なかったＳTM は原子尺度の空間分解能を有している ので，局所状態密度も原子スケールで調べることが可能 でありここれは現在使用できる究極の表面分光法でする と言えよう。

STM で局所状態密度が測定されるこ亡は表面電子分 光にとっては素晴らしいことではあるが，反面，表面構 造の研究によっては，この特徴はかえって事態を複雑な ものにする結果をもたらしている，というのも，表面の 局所状態密度の卜ポグラフは必ずしも表面の原子配列に 一致しておらず，この差は特に半導体表面に执いて顕著 になっているからである，表面原子間の電荷移動が大き い場合には局所状態密度が表面のある特定の原子に偏在 することがあり，そのような場合にはSTMではそ机ら の特定の原子しかイメージされない，またバイアス電生 によって STM 像が変化するため, 正しい構造解析を行 なうためには，દ゙うしてもSTM 像の正しい“解积”が 必要になってくる。したがって“百聞は一見にしかず” であるが，半導体ではSTM 像の山の所が必す原子に対 応しているとは限らないので，STM 像を正しく見るた めには電子状態の知識も含めた豊かな眼力が必要なので
ある。

\section{3 半導体表面の STM 像}

前節で述べたように，半導体表面のSTM 像はバイア 又電压によって変化するため, 本来は走查トンネル分光 法 (STS) の対称であるが，ここでいくつかの例を簡単 に紹介することにする.

図 6 は図 3 と同じくSi (111) $7 \times 7$ であるが，単位格 子内の吸着原子, 四隅の穴がより明りょうにイメージさ れている。

Si (111)面を真空中でへき開すると，準安定の $2 \times 1$ 構造が出現する。 この表面の STM 像を図 7 に示す，鲳 状の山は表面原子が作る $\pi$-bonded chain に対応して おり，バイアス電圧を逆転させても山の位置は変的らな い、このことは $\pi$-bonded chain 構造の存在を寒付け る実験的証拠上されている.

Si (100) 表面では原子が対になって dimer を形成して いるが，STM ではダイマーは茠状にイメージされ，そ

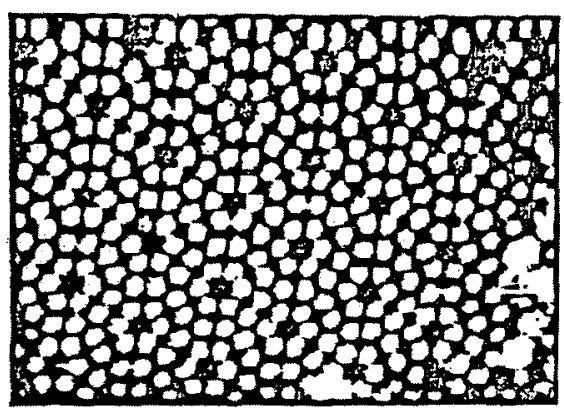

図 $6 \mathrm{Si}(111) 7 \times 7$ の高分解能 STM 像

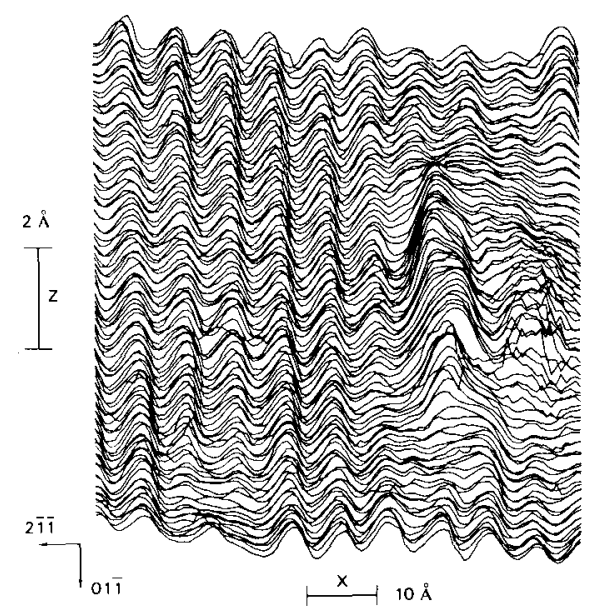

図 $7 \mathrm{Si}(111) 2 \times 10 \mathrm{STM}$ 像, 㑼状の起伏が $\pi$-bon ded chain に対応している 


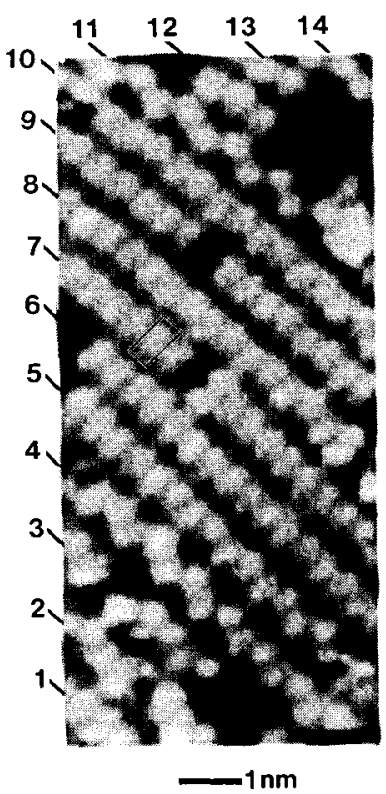

図 8 Si (100) の STM 像
れらが整然と並んだ様子が観察される(図8). Dimer が抜け落ちた欠宿がかなり多く見ら扟るここは興味深 W.

GaAs (110) 面はバイアス電理によってSTM 像が変 化する典型例である，電子が As に偏在しているため に，試料を正にバイアスする上Gaがイメージされ，負 バイアスではAsがイメージさ扟る（図9）.

\section{4 探針の役割}

STM は基本的には探針で試料表面を“なぞる”装置 であるから，探針先端が尖鋭であればあるはよ゙，分解能 は高くなるはずである。それでは原子尺度の分解能を得 るためには上゙の程度尖鋭であれば良いか，と言うと， Tersoff-Hamannの理論によれば，必要な探針先端の 曲率半径は $10 \AA$ 程度以下である。現在，機械研磨や電 界研磨で作られる探針の曲率半径は数 $100 \AA$ であるか ら，STM で原子を見ることは不可能なはずである。 Binnig 早初は原子尺度の分解能が得的机る上は予想 していなかったことが知られている，をれにもかかわら ず，STM で原子が観察できる理由は，現在の上ころ， 探針の先端に小さな原子集団があり，トンネル電流がそ の上うな突起在通して流れるためであると解积されてい ろ。原子数個の突起が表面に残ること恃言わば偶然の産

物でするから，時には適当に機械研磨しただけの 探針でも原子在観察できる場合がある，Binnig
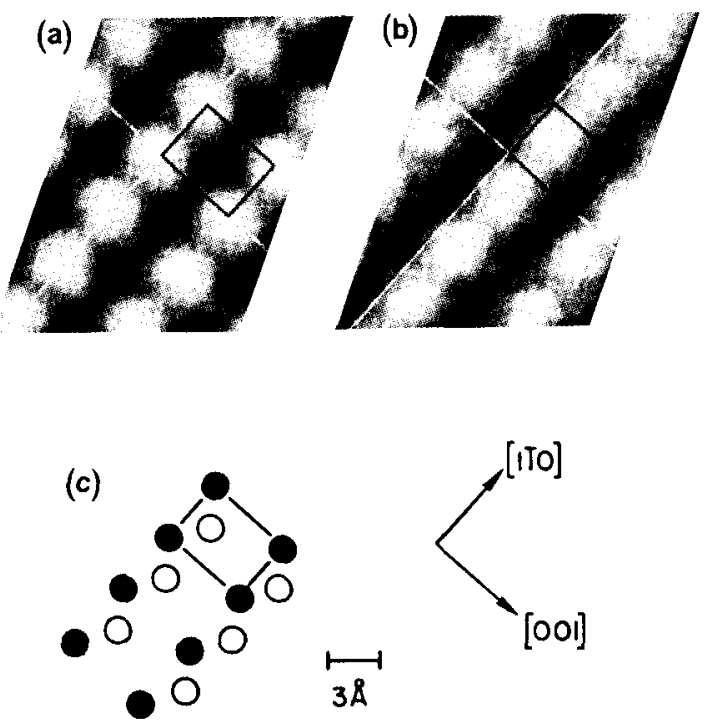

圂 9 GaAs (110) のSTM 像の電圧依存性. (a), (b) はそれぞれ試料電圧が+1.0 V, $-1.9 \mathrm{~V}$ の時のSTM 像. (c) は GaAs (110) の原子配直で, 白丸はAs, 黑丸は Gaを表わしている.（c）の長方形が (a)，(b)の長方形 に対応している，(a) ではGa，(b) ではsのみがイ メージされている らが簡槑な研磨針で Si（111）7×7の原子構造を イメージできた理由もここにある。

しかしながら，偶然に表面にある原子クラス 夕一利用していては，再現性良くSTM 像在得 ることは困難であり，よ゙うしても探針先端の表面 在亦らかじ評価して拉くことが必要上なってく る。この探針評価に将に最適な手法が，最初に述 べた FIMである、1.で説明さ机ているように，FI Mは針の表面の原子構造を観察する装置である から，STM 探針の表面の原子装置在FIM で容 易に調心るるこができる，FIMでは平たんな表面 の原子構造を観るこしは難しいが, STMで重要 な原子クラスターは明るくイメージされるため, $\mathrm{STM}$ 探針の評価にはまさにうってつけの装置で あると害える。

FIMの利点は単に探針表面の観察だけによよ゙ま らない，既に1で述べたようにＦIMを用いる 上，電界蒸発用いて表面原子夕ラスターの大き さを人工的に制卸することができる、この手法に より表面に数個の原子を残して㧍，高分解能の STM 探針作製することも可能となる。

STMに和引るFIMの重要性は早くから研究者 の間て認識されていたが，最初にSTMよFIM 
を組み合わせた装置は1986 年に Bell Labsの Kukに より開発され，また筆者の研究室でも FIM-STM が稼 動している．STMにFIM 結含する方式は世界的に 広まりつつあり，今後数年間に多くの FIM-STM が作 られるものと予想される。

筆者の研究室の FIM-STM の模式図を図 10 に示す. STM ユニットはいわゆるDemuth 型で，探針は上に 向いており，試料はレバー機構により探針にかぶさるよ
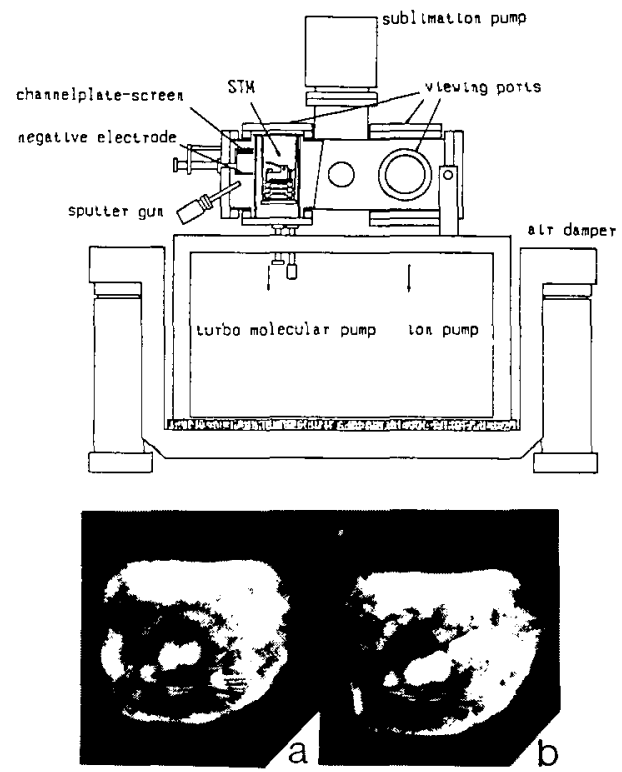

図10 物性研究所の FIM-S'TM の模式図（上），抽上 び同装置で得られたW探針の FIM 像 (下)

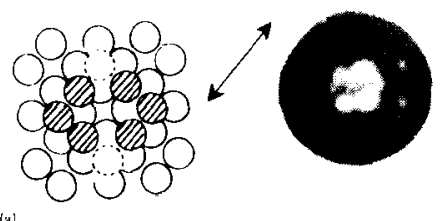

(a)

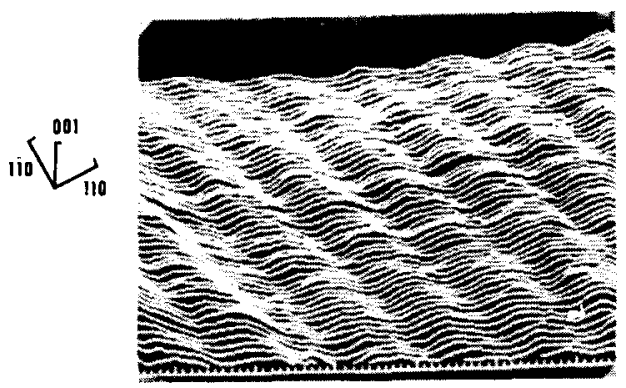

うにして接近する。試料を遠ざけた状態で，側面から FIM ユニットを探針の真上に移動させると，上方の瞀 き惫から電界イオン像を観察できる. FIM ユニットは 通常のチャンネルプレート, スクリーンの他に, 引出し 電極が含まれている。これはピエゾ素子に取り付けられ た探針に高電圧を加えるここができないために，探針の 近傍に負の高電圧を加えた引出し電極を㯰く必要がある のである。この装置で撮られたタングステン探針の電界 イオン像は図 10 に示されている.

探針先端の原子クラスターが STM の分解能を左右し ていることは，Kukらによって明らかにされた，金の (100) 面の場合, FIM で観察されたクラスターの大きさ が小さいときには測定される表面の起伏も大きい（図 11(b)）のに対して，大きなクラスターでは起伏も小さ

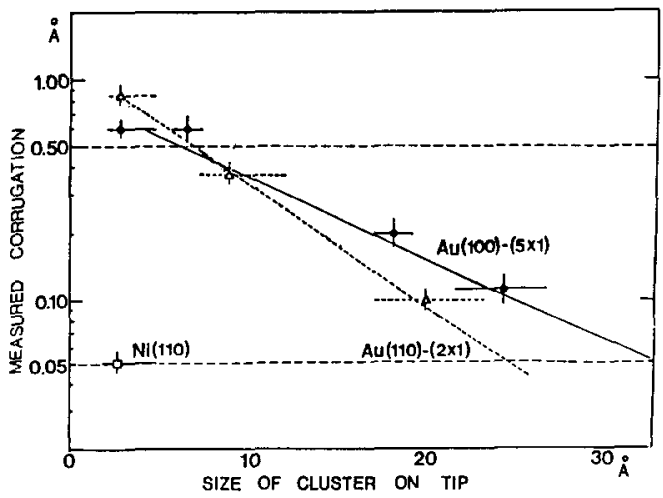

図12 STM によって測定される表面の起伏の大きさ と, 探針先端の原子クラスターの大きさの関掭
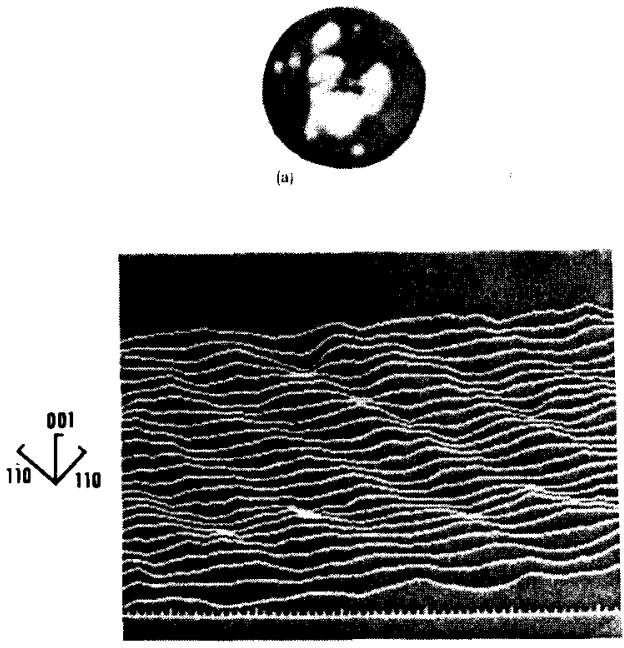

図11 Au (100)のSTM 像と探針の FIM 像，探針先湍の原子集団が小さい((a)) 時には 観測さ扎る表面の起伏が大きいのに対して、探針先端の原子集団が大きい（(b)）時には起伏 も少さくなり，分解能も低下する 
く測定されてしまう(図 11(a)). 彼らは種々のクラス ターサイズに対して表面の起伏を測定し，図 12 の結果 を得た，図から明らかなように，起伏の大きさはクラス ターが大きくなると指数関数的に減少しており，装置の ノイズレベルより大きい起伏を得るためには十分小さな クラスターを持った探針を用いることが必要である。こ のことは探針先端のクラスターの重要性を如実に示して いる.

探針表面のクリーニング，すなわち酸化物の除去につ いては，その必要性についての議論があるが, FIMを 用いた場合には，電界脱離により酸化物は自動的に除去 されてしまう。この点でも FIMを使用する利点は大き w.

\section{5 おわりに}

STM は単に表面原子を観察する手法としてばかりて はなく, 分光法により表面の電子状態を調べるまでに発 展してきている。しかし，まだSTM 測定の成功率はそ れはよ゙高くはなく必ずしも完成された手法とは云い難 い。これはおもにSTM 挆針に原因があると考えられ， 特に探針の波動関数や，それが STMに与える効果につ いて怀明の点が多く, 今娞の研究の蓄積が必要であ る. FIM はそのための鼠も強力な手法として. 広く活 用されることが期待される。

\section{文献}

1) F.W. Mueller and T.T. Tsong, Field Ion Microscopy, Principles and Applications, (Elsevicr. New York, 1969).
2) R.D. Young, J. Ward, and F. Scire, Phys. Rev. Lett., 27, 922 (1971).

3) R.D. Young, J. Ward, and F. Scire, Rev. Sci. Instrum., 43, 999 (1972).

4) G. Binning, H. Rohrer, Ch. Gerber, and E. Weibel, Phys. Rev. Lett., 49, 57 (1982).

5) G. Binning, H. Rohrer, Ch. Gerber, and E. Weibel, Phys. Rev. Lett., 50, 120 (1983).

6) 以下の解説を参照 IBM J. Res. Dev., 30, Nos. 4 and 5 (1986);Surf. Sci., 181, 1-142 (1987);J. Vac. Sci. and Technol., A 6, 257-554 (1988).

7) J. Tersoff and D.R. Hamann, Phys. Rev., B 31 , 805 (1985)

8) J.E. Demuth, R.J. Hamers, R.M. Tromp, and M. E. Walland, J. Vac. Sci. and Technol., A 4, 1320 (1986).

9) R.M. Feenstra, W.A. Thompson, and A.P. Fein, Phys. Rev. Lett., 56, 608 (1986).

10) K.C. I'andey, Phys. Rev. Lett., 49, 223 (1982).

11) R.J. Hamers, R.M. Tromp, and J.E. Demuth, Phys. Rev. B 34, 1388 (1986).

12) R.M. Feenstra, J.A. Stroscio, J. Tersoff, and $\Lambda$. P. Fein, Phys. Rev. Lett., 55, 1192 (1987).

13) Y. Kuk and P'.J. Silverman Appl. Phys. Lett, 48, 1597 (1986).

14) T.Sakurai, T. Itashizume, I. Kamiya, Y. Hasegawa, A. Sakai, A. Kobayashi, J. Matsui, S. Takahashi, I: Kono, and H. Watarabe, J. de Phys. Colloque, 48, C 6-79 (1987).J.Vac Sci, and Technol.A6 803(1988)

15) Y. Kuk, P.J. Silverman, and N.Q. Nguyen, $J$. Vac. Sci. Technol, A 6, 521 (1988).

(本解説は本年 6 月号解説特集 ISTM $の$ 固体表面観 察への応用と展望」の続きとなるものです） 